\title{
Spatial distribution and sources of organic carbon in the surface sediment of Bosten Lake, China
}

\author{
Z. T. Yu ${ }^{1,2,3}$, X. J. Wang ${ }^{1,4,5}$, E. L. Zhang ${ }^{6}$, C. Y. Zhao ${ }^{1}$, and X. Q. Liu ${ }^{7}$ \\ ${ }^{1}$ State Key Laboratory of Desert and Oasis Ecology, Xinjiang Institute of Ecology and Geography, Chinese Academy of \\ Sciences, 830011 Urumqi, China \\ ${ }^{2}$ College of Resources and Environmental Sciences, Xinjiang University, 830046 Urumqi, China \\ ${ }^{3}$ University of Chinese Academy of Sciences, 100049 Beijing, China \\ ${ }^{4}$ College of Global Change and Earth System Science, Beijing Normal University, 100875 Beijing, China \\ ${ }^{5}$ Earth System Science Interdisciplinary Center, University of Maryland, College Park, MD 20740, USA \\ ${ }^{6}$ State Key Laboratory of Lake Science and Environment, Nanjing Institute of Geography and Limnology, Chinese Academy \\ of Sciences, 210008 Nanjing, China \\ ${ }^{7}$ College of Resource Environment and Tourism, Capital Normal University, 100048 Beijing, China
}

Correspondence to: X. J. Wang (xwang@bnu.edu.cn)

Received: 9 July 2015 - Published in Biogeosciences Discuss.: 25 August 2015

Revised: 5 November 2015 - Accepted: 10 November 2015 - Published: 19 November 2015

\begin{abstract}
Lake sediment is an important carbon reservoir. However, little is known on the dynamics and sources of sediment organic carbon in Bosten Lake. We collected 13 surface $(0-2 \mathrm{~cm})$ sediment samples in Bosten Lake and analyzed total organic carbon (TOC), total nitrogen (TN), stable carbon isotopic composition in TOC $\left(\delta^{13} \mathrm{C}_{\text {org }}\right)$, and grain size. We found a large spatial variability in TOC content (1.8$4.4 \%)$ and $\delta^{13} \mathrm{C}_{\text {org }}$ value ( -26.77 to $-23.98 \%$ ). Using a three-end-member mixing model with measured TOC:TN ratio and $\delta^{13} \mathrm{C}_{\text {org }}$, we estimated that $54-90 \%$ of TOC was from autochthonous sources. Higher TOC content (>3.7\%) was found in the east and central-north sections and near the mouth of the Kaidu River, which was attributable to allochthonous, autochthonous plus allochthonous, and autochthonous sources, respectively. The lowest TOC content was found in the mid-west section, which might be a result of high kinetic energy levels. Our study indicated that the spatial distribution of sediment TOC in the Bosten Lake was influenced by multiple and complex processes.
\end{abstract}

\section{Introduction}

Inland water bodies such as rivers and lakes are unique components on the Earth. In spite of their relatively small coverage (Downing et al., 2006), lakes often receive a large amount of terrestrial materials from the watersheds (Battin et al., 2009; Anderson et al., 2013) and store a significant amount of carbon in the sediments (Ferland et al., 2012; Tranvik et al., 2009). Thus, inland lakes may play an important role in the terrestrial carbon cycle. Compared to the oceans, lakes have active biogeochemical processes with stronger "biological pump", which often leads to higher sedimentation rates and a large amount of organic carbon (OC) burial at the bottom of lakes (Dean and Gorham, 1998).

There have been a number of studies from North America (Dean and Gorham, 1998), western Europe (Bechtel and Schubert, 2009; Woszczyk et al., 2011), eastern Asia (Khim et al., 2005; Wang et al., 2012), and other regions (Dunn et al., 2008), showing large spatial variability in total organic carbon (TOC) of lake sediment. The magnitude of TOC in surface sediment may depend on many factors, including column water productivity, terrestrial inputs of organic materials, properties of sediment, and rate of microbial activity (Burone et al., 2003; Gireeshkumar et al., 2013). Among them, contributions of autochthonous and allochthonous sources have direct impacts on the spatial dis- 
tribution, which varies largely across regions (Bechtel and Schubert, 2009; Anderson et al., 2009), partly due to differences in lake productivity and morphology (Barnes and Barnes, 1978). In general, lakes with high productivity have more autochthonous TOC, but lakes with low productivity mainly allochthonous TOC (Dean and Gorham, 1998). There is evidence of littoral sources of TOC in small and shallow lakes but autochthonous sources, derived from planktonic organisms, in larger and deeper lakes, especially fjord lakes (Shanahan et al., 2013; Sifeddine et al., 2011; Barnes and Barnes, 1978).

A number of techniques have been applied to quantify different sources of sediment TOC (Fang et al., 2014; Hanson et al., 2014; Meyers and Ishiwatari, 1993; Bechtel and Schubert, 2009). One of the common approaches is to use twoor three-end-member mixing models with combined use of TOC to total nitrogen $(\mathrm{TN})$ ratio $(\mathrm{C}: \mathrm{N})$ and stable carbon isotope in organic material $\left(\delta^{13} \mathrm{C}_{\text {org }}\right.$ ) (Rumolo et al., 2011; $\mathrm{Yu}$ et al., 2010; Liu and Kao, 2007). It is well known that there are large differences in $\mathrm{C}: \mathrm{N}$ ratio and ${ }^{13} \mathrm{C}_{\text {org }}$ value between exogenous and endogenous organic materials (Brodie et al., 2011; Kaushal and Binford, 1999). For example, aqueous organic matter has low $\mathrm{C}: \mathrm{N}$ ratios (4-10) (Meyers, 2003) whereas vascular land plants have much higher $\mathrm{C}: \mathrm{N}$ ratios (> 20) (Rumolo et al., 2011; Lamb et al., 2004; Sifeddine et al., 2011). On the other hand, due to the difference in isotopic fractionation during photosynthesis, $\delta^{13} \mathrm{C}_{\text {org }}$ value is more negative (ranging from -33 to $-22 \%$ ) in terrestrial $\mathrm{C}_{3}$ plants (Pancost and Boot, 2004; Wang et al., 2013) and lake plankton (Bertrand et al., 2010; Vuorio et al., 2006) than in $\mathrm{C}_{4}$ plants (ranging from -16 to $-9 \%$ ) (Pancost and Boot, 2004; Wang et al., 2013).

Bosten Lake, as the largest lake in Xinjiang of China, is a typical place for studying lake carbon cycle. Previous studies have provided evaluations on water quality (Wu et al., 2013), changes in lake level (Guo et al., 2014), and the controlling factors of carbon and oxygen isotopic composition of surface sediment carbonate (Zhang et al., 2009). A recent study indicated that particulate organic carbon (POC) variability in the water column was affected by allochthonous sources in Bosten Lake (Wang et al., 2014). However, little has been done to assess the dynamics and sources of sediment TOC in Bosten Lake. Therefore, this study was designed to evaluate the spatial distributions of major physical and biogeochemical parameters in the surface sediment, and to quantify the contributions of various sources to the sediment TOC in Bosten Lake.

\section{Materials and methods}

\subsection{Site description}

Bosten Lake $\left(41^{\circ} 32^{\prime}-42^{\circ} 14^{\prime} \mathrm{N}, 86^{\circ} 19^{\prime}-87^{\circ} 26^{\prime} \mathrm{E}\right)$ is located in the lowest part of the intermontane Yanqi Basin between the Taklimakan Desert and Tien Shan, northwestern China (Fig. 1). It is the largest inland freshwater lake in China, which is about $55 \mathrm{~km}$ long from east to west and about $25 \mathrm{~km}$ wide from south to north, comprising a total lake surface area of approximately $1005 \mathrm{~km}^{2}$, with a maximum water depth of $14 \mathrm{~m}$ (Wu et al., 2013). The lake surface was $1045 \mathrm{~m}$ above sea level in 2012 when sampling was carried out. The lake lies in the center of the Eurasian continent and is influenced by a temperate continental climate. The mean annual air temperature is approximately $8.3^{\circ} \mathrm{C}$, the mean annual precipitation approximately $65 \mathrm{~mm}$, and the mean annual evaporation approximately $1881 \mathrm{~mm}$ (Zhang et al., 2009). Winds come mainly from the southwest, indicating dominant influence by westerlies throughout the summer season. Lake water input mainly comes from the Kaidu River that is supplied by melting ice, precipitation, and groundwater, whereas water output includes outflow $(57 \%)$ via the Peacock River and evaporation (43\%) (Guo et al., 2014). There are also small seasonal rivers (mainly during flood seasons), e.g., the Huangshui River and Qingshui River near the northwest of the lake.

\subsection{Field sampling and analyses}

For the present study, a Kajak gravity corer was used to collect surface sediments from 13 sites in the main section of Bosten Lake in August 2012 (Fig. 1). The sampling sites covered most parts of the lake, with water depths ranging from 3 to $14 \mathrm{~m}$. The sediment cores were carefully extruded, and the top $2 \mathrm{~cm}$ sections were sliced into $1 \mathrm{~cm}$ and placed in polyethylene bags that were kept on ice in a cooler during transport and before analyses.

Following Liu et al. (2014), each sediment sample $(\sim 0.5 \mathrm{~g})$ was pretreated, in a water bath (between 60 and $80^{\circ} \mathrm{C}$ ), with $10-20 \mathrm{~mL}$ of $30 \% \mathrm{H}_{2} \mathrm{O}_{2}$ to remove organic matter, then with $10-15 \mathrm{~mL}$ of $10 \% \mathrm{HCl}$ to remove carbonates. The samples were then mixed with $2000 \mathrm{~mL}$ of deionized water, and centrifuged after $24 \mathrm{~h}$ of standing. The solids were dispersed with $10 \mathrm{~mL}$ of $0.05 \mathrm{M}\left(\mathrm{NaPO}_{3}\right)_{6}$, then analyzed for grain size, using a Malvern Mastersizer 2000 laser grain size analyzer at the State Key Laboratory of Lake Science and Environment (SKLLSE), Nanjing Institute of Geography and Limnology, Chinese Academy of Sciences (CAS). The Malvern Mastersizer 2000 automatically outputs the median diameter $d(0.5)(\mu \mathrm{m})$, the diameter at the 50th percentile of the distribution, and the percentages of clay $(<2 \mu \mathrm{m})$, silt $(2-64 \mu \mathrm{m})$, and sand $(>64 \mu \mathrm{m})$ fractions.

Sediment $\mathrm{C}$ and $\mathrm{N}$ contents were measured using an Elemental Analyzer 3000 (Euro Vector, Italy) at the SKLLSE, Nanjing Institute of Geography and Limnology, CAS. All samples were freeze-dried and ground into a fine powder, then placed in tin capsules, weighed, and packed carefully, according to Eksperiandova et al. (2011). For the analysis of TOC, each sample $(\sim 0.3 \mathrm{~g})$ was pretreated with $5-10 \mathrm{~mL}$ $2 \mathrm{M} \mathrm{HCl}$ for $24 \mathrm{~h}$ at room temperature to remove carbonate, 


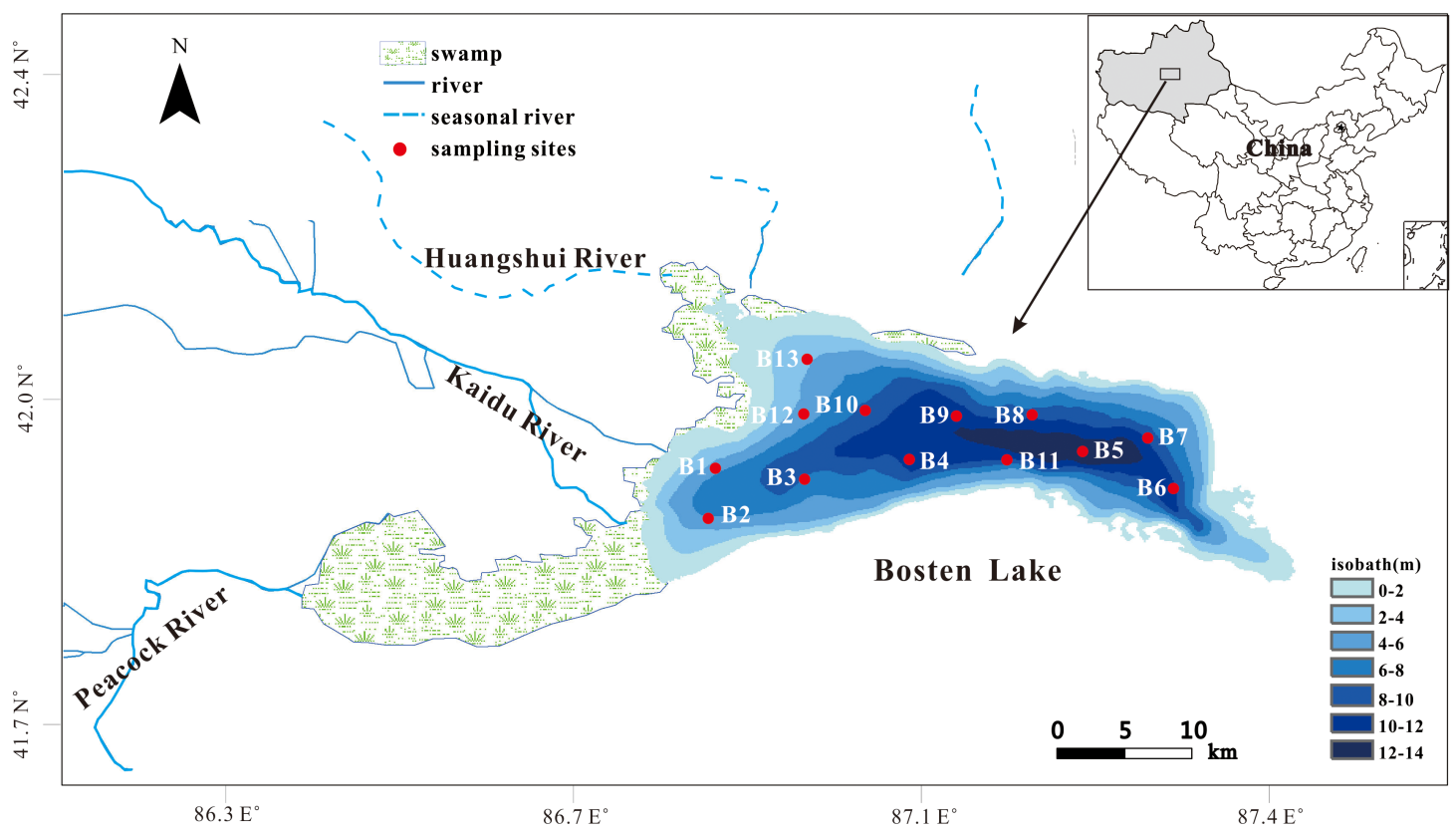

Figure 1. Map of Bosten Lake with the water depth and the 13 sampling stations (red dotes). Bathymetry was measured in 2008 by Wu et al. (2013) and bathymetric contours were plotted by using software ArcGIS 9.3 and CorelDraw X3.

dried overnight at $40-50^{\circ} \mathrm{C}$, then analyzed for $\mathrm{C}$ content using the Elemental Analyzer.

For the analyses of $\delta^{13} \mathrm{C}_{\text {org }}$, approximately $0.2 \mathrm{~g}$ of the freeze-dried sediment sample was pretreated with $5-10 \mathrm{~mL}$ $2 \mathrm{M} \mathrm{HCl}$ for $24 \mathrm{~h}$ at room temperature to remove carbonate, and then rinsed to a $\mathrm{pH}$ of approximately 7 with deionized water and dried at $40-50{ }^{\circ} \mathrm{C}$ (Liu et al., 2013). The pre-treated samples were combusted in a Thermo elemental analyzer integrated with an isotope ratio mass spectrometer (Delta Plus XP, Thermo Finnigan MAT, Germany). Isotopic data were reported in delta notation relative to the Vienna Pee Dee Belemnite (VPDB).

\subsection{Calculations of TOC sources}

We applied a three-end-member mixing model (Liu and Kao, 2007 ) to quantify the contributions $(f)$ of three sources (i.e., soil, terrestrial plant, and lake plankton, denoted by 1,2 , and 3 , respectively):

$\delta=f_{1} \delta_{1}+f_{2} \delta_{2}+f_{3} \delta_{3}$,

$r=f_{1} r_{1}+f_{2} r_{2}+f_{3} r_{3}$,

$1=f_{1}+f_{2}+f_{3}$,

where $\delta$ and $r$ are $\delta^{13} \mathrm{C}_{\text {org }}$ value and $\mathrm{C}: \mathrm{N}$ ratio, respectively.

Given that there were limited crops around the lake and most crops' growing season was less than 5 months each year, we assumed that native plants, mainly reed (Phragmites australis (Cav.) Trin. ex Steud.), Manaplant Alhagi (Alhagi sparsifolia Shap) and Achnatherum splendens (Achnatherum splendens (Trin.) Nevski), were responsible for terrestrial plant's contribution. Based on our recent studies conducted in the Yanqi Basin (Wang et al., 2015; Zhang, 2013), C:N ratio was $22.1 \pm 9.9$ and $10 \pm 1.8$, and $\delta^{13} C_{\text {org }}$ value was $-26.4 \pm 1.2$ and $-23.6 \pm 1.3 \%$ o for the native plants and surface soils around the lake, respectively. We used the values as the end-members for the mixing model.

We measured POC, particulate organic nitrogen (PON), and $\delta^{13} \mathrm{C}_{\text {org }}$ in POC in the water column of Bosten Lake (Wang et al., 2014). Lake POC and PON increased from $0.61 \pm 0.04 \mathrm{mg} \mathrm{C} \mathrm{L}^{-1}$ and $0.072 \pm 0.005 \mathrm{mg} \mathrm{N} \mathrm{L}^{-1}$ in spring to $0.70 \pm 0.16 \mathrm{mg} \mathrm{C} \mathrm{L}^{-1}$ and $0.088 \pm 0.02 \mathrm{mg} \mathrm{N} \mathrm{L}^{-1}$ in summer, and $\delta^{13} \mathrm{C}_{\text {org }}$ value in POC was $-22.9 \pm 2.56 \%$ in spring and $-23.5 \pm 0.38 \%$ in summer. It is reasonable to assume that the seasonal changes resulted from the production of lake plankton. Accordingly, we estimated that lake plankton (including phytoplankton and zooplankton) would have a $\mathrm{C}: \mathrm{N}$ ratio of 5.3 and $\delta^{13} \mathrm{C}_{\mathrm{org}}$ value of $-27.7 \%$, and used these values as the end-members for the mixing model.

Our approach may have uncertainties in determining TOC sources. However, the uncertainties would be small given that the standard errors in $\delta^{13} \mathrm{C}_{\text {org }}$ are small, and $\mathrm{C}: \mathrm{N}$ ratios differ greatly between sources. Thus, our method will not affect the main conclusion in terms of TOC sources for the lake sediments.

\subsection{Statistical methods and mapping}

Correlation analyses were performed using the SPSS Statistics 19 for Windows. Spatial distribution maps were produced using Surfer 9.0 (Golden Software Inc.), and the kriging method of gridding was used for data interpolation. 

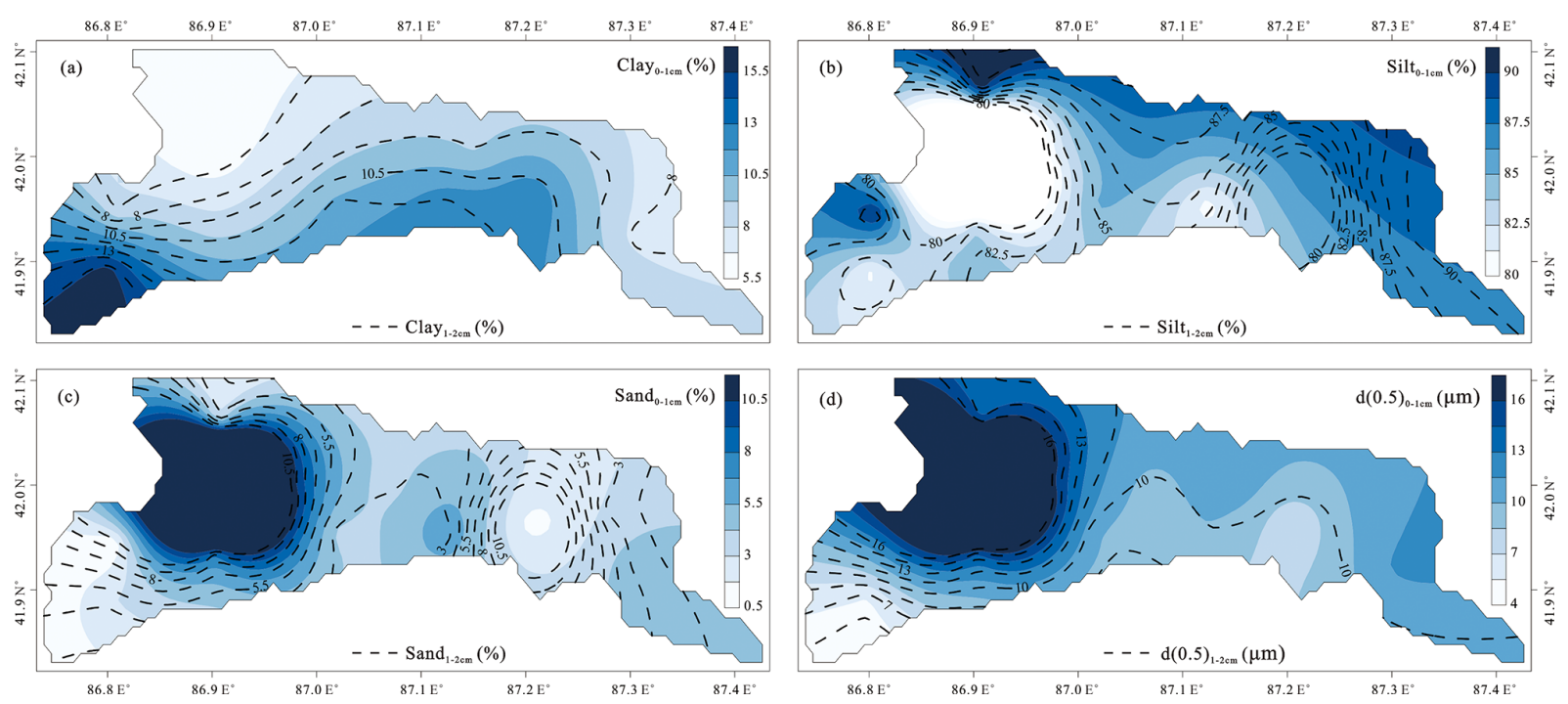

Figure 2. Distributions of (a) clay, (b) silt, (c) sand, and (d) the median diameter $(d(0.5), \mu \mathrm{m})$ in the $0-1 \mathrm{~cm}$ (color map) and $1-2 \mathrm{~cm}(\mathrm{dashed}$ lines). The spatial distribution maps (Fig. 2-7) were produced using Surfer 9.0 (Golden Software Inc.), and the interpolated data in the maps were found using the kriging method of gridding.

\section{Results}

\subsection{Physical characteristics}

Figure 2 showed the spatial distributions of the main granulometric variables of the surface sediment. In general, clay content was low (6-17\%), showing relatively higher values in the southern part than in the northern part. The highest clay content was found in the southwest and the lowest in the northwest section. On the other hand, silt content was much higher (greater than $80 \%$ ) with clearly higher values near the mouths of the Kaidu River (southwest) and Huangshui River (northwest). The lowest content of silt was found in the mid-west, between the rivers' mouths, where sand content was highest (Fig. 2c). As expected, the spatial distribution of $d(0.5)$ was similar to that of sand, showing the highest values in the mid-west section, indicating strong hydrodynamic effect in this area.

\subsection{Spatial distribution of TOC, TN, C:N, and $\delta^{13} \mathrm{C}_{\text {org }}$}

Concentration of TOC was highly variable, with higher values (4.3-4.4\%) found in the northern and eastern sections of the lake (Fig. 3a). There was also high concentration of TOC (4.1-4.2\%) near the mouth of the Kaidu River (southwest). On the other hand, lower TOC concentration (1.8-2.4\%) was observed in the mid-west section. Similarly, TN concentration (ranging from 0.28 to $0.68 \%$ ) was lowest in the midwest and highest in the northwest and east sections (Fig. 3b). Overall, the spatial distribution of TN was similar to that of TOC. The exception was in the northwest area that had a high TN value but low TOC concentration.
Figure 4a showed a large spatial variability in the $\mathrm{C}: \mathrm{N}$ ratio with a range from 4.6 to 8.6. In general, $\mathrm{C}: \mathrm{N}$ ratio was higher in the central part relative to other parts. The highest $\mathrm{C}: \mathrm{N}$ ratio was found in the mid-west and the lowest found in the northwest area. The $\delta^{13} \mathrm{C}_{\text {org }}$ values ranged from -26.77 to $-23.98 \%$ o (Fig. $4 \mathrm{~b}$ ). The most negative value was observed in the area of $41.9-42^{\circ} \mathrm{N}$ and $86.9-87^{\circ} \mathrm{E}$ and the least negative value near the mouth of the Huangshui River (northwest). Overall, values of $\delta^{13} \mathrm{C}_{\text {org }}$ were more negative in the eastern and central parts than in the northwestern and southwestern parts.

\subsection{Contributions of different sources}

Using the three-end-member mixing model, we calculated the contributions of autochthonous and allochthonous sources to the surface sediment TOC. As shown in Fig. 5a, the contribution of lake plankton ranged from 54 to $90 \%$, with the highest in the western shallow lake area, and the lowest in the southern and eastern deep lake area. The contribution of soils varied between 10 and $40 \%$, with the highest in the southeast and central south area (Fig. 5b). Apparently, the contribution from native plants was extremely low $(<4 \%)$, with only a few sites showing values of $10-12 \%$ (Fig. 5c). On average, the contributions from lake plankton, soils, and native plants were 66,30 , and $4 \%$, respectively.

There were large differences in the spatial distributions of TOC between the autochthonous and allochthonous sources. Autochthonous TOC revealed highest value $(\sim 3.5 \%)$ near the mouth of the Kaidu River and lowest $(\sim 1.5 \%)$ in the mid-west of the lake (Fig. 6a). For the area east of $87^{\circ} \mathrm{E}$, autochthonous TOC showed a clear increase from south to north. On the other hand, there was an apparent elevation in 

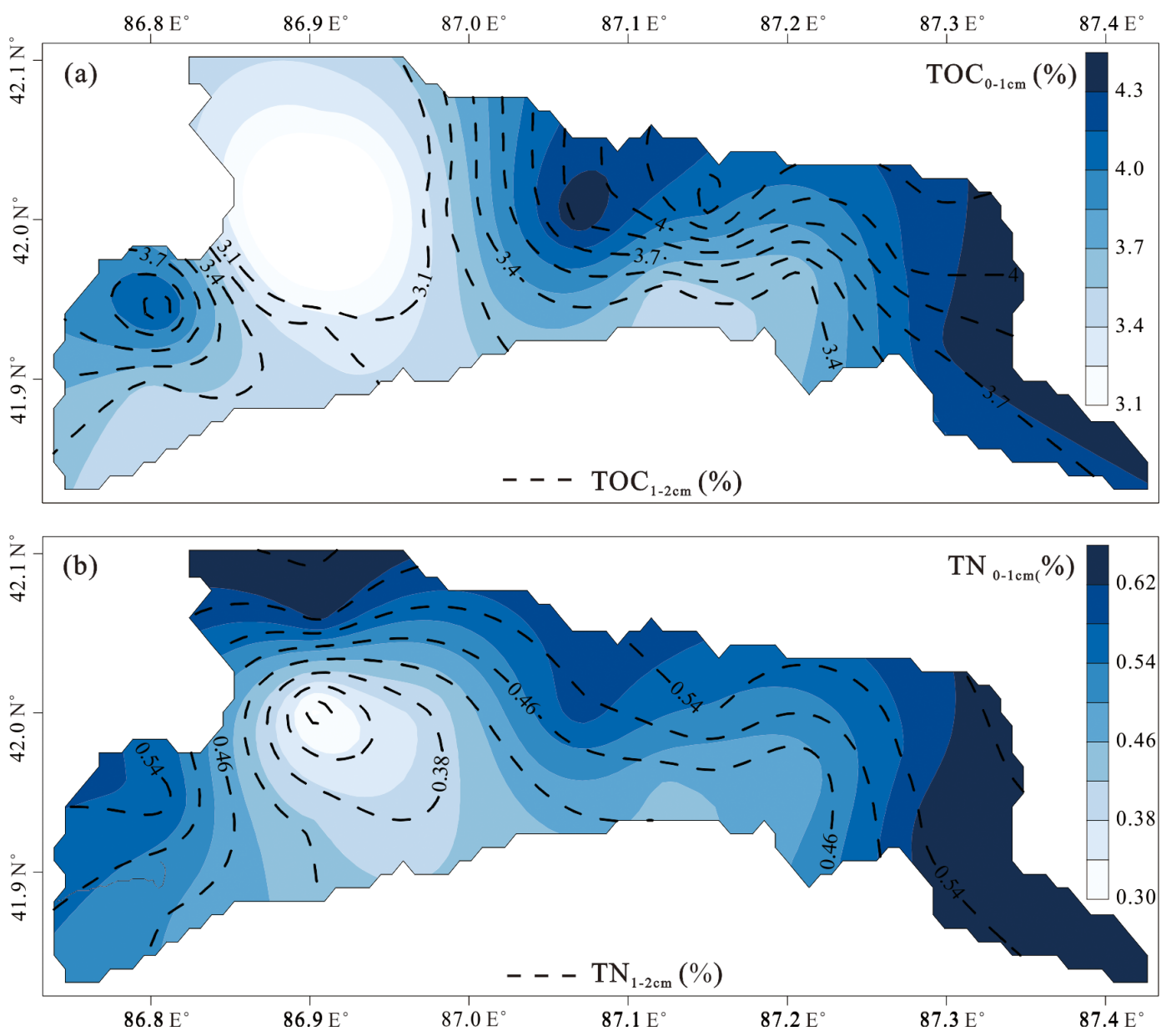

Figure 3. Spatial distributions of (a) total organic carbon (TOC) and (b) total nitrogen (TN) in the 0-1 cm (color map) and 1-2 cm (dashed lines).

the allochthonous TOC, from $0.5 \%$ in the west to $1.9 \%$ in the east (Fig. 6b).

\section{Discussion}

The concentration of TOC in the surface sediment of Bosten Lake ranged from 1.8 to $4.4 \%$, which was relatively higher than those $(0.2-2 \%)$ in the Tibetan Plateau (Lami et al., 2010; Wang et al., 2012) and Yangtze floodplain (Wu et al., 2007; Dong et al., 2012), but much lower than those (5$13 \%$ ) in the lakes of the Yunnan-Guizhou Plateau (Zhu et al., 2013; Wu et al., 2012). Low TOC contents in the Tibetan Plateau lakes were a consequence of low biological productivity owing to the high altitude and low temperature (Lami et al., 2010). Although lakes in the Yangtze floodplain had higher productivity in the water column due to eutrophication (Qin and Zhu, 2006), most of them were shallow lakes that were subject to frequent turbulence and resuspension of sediments (Qin et al., 2006). In addition, warm-humid climate in the Yangtze floodplain could promote decomposition of
POC in the water column and TOC in the sediments (Gudasz et al., 2010), which led to less TOC storage in the surface sediments. On the other hand, lakes in the Yunnan-Guizhou Plateau were deep with higher lake productivity, which had favorable TOC burial conditions (Jiang and Huang, 2004).

Sediment organic compounds are either of terrestrial origins or derived from phytoplankton and zooplankton remains and feces (Meyers, 2003; Meyers and Ishiwatari, 1993; Barnes and Barnes, 1978). A number of studies have demonstrated that TOC in small and shallow lakes is attributable to allochthonous sources but TOC in larger and deeper lakes to autochthonous sources that are derived from planktonic organisms (Shanahan et al., 2013; Sifeddine et al., 2011; Barnes and Barnes, 1978). Our analyses showed that the majority of TOC was autochthonous in the surface sediment of Bosten Lake. We also found a significant negative relationship between TOC and dry bulk density (Table 1), confirming that higher TOC (with lighter weight) would be a result of sedimentation of non-terrestrial organic materials.

Our study demonstrated large spatial variability in the TOC of the surface sediment in Bosten Lake, with higher val- 

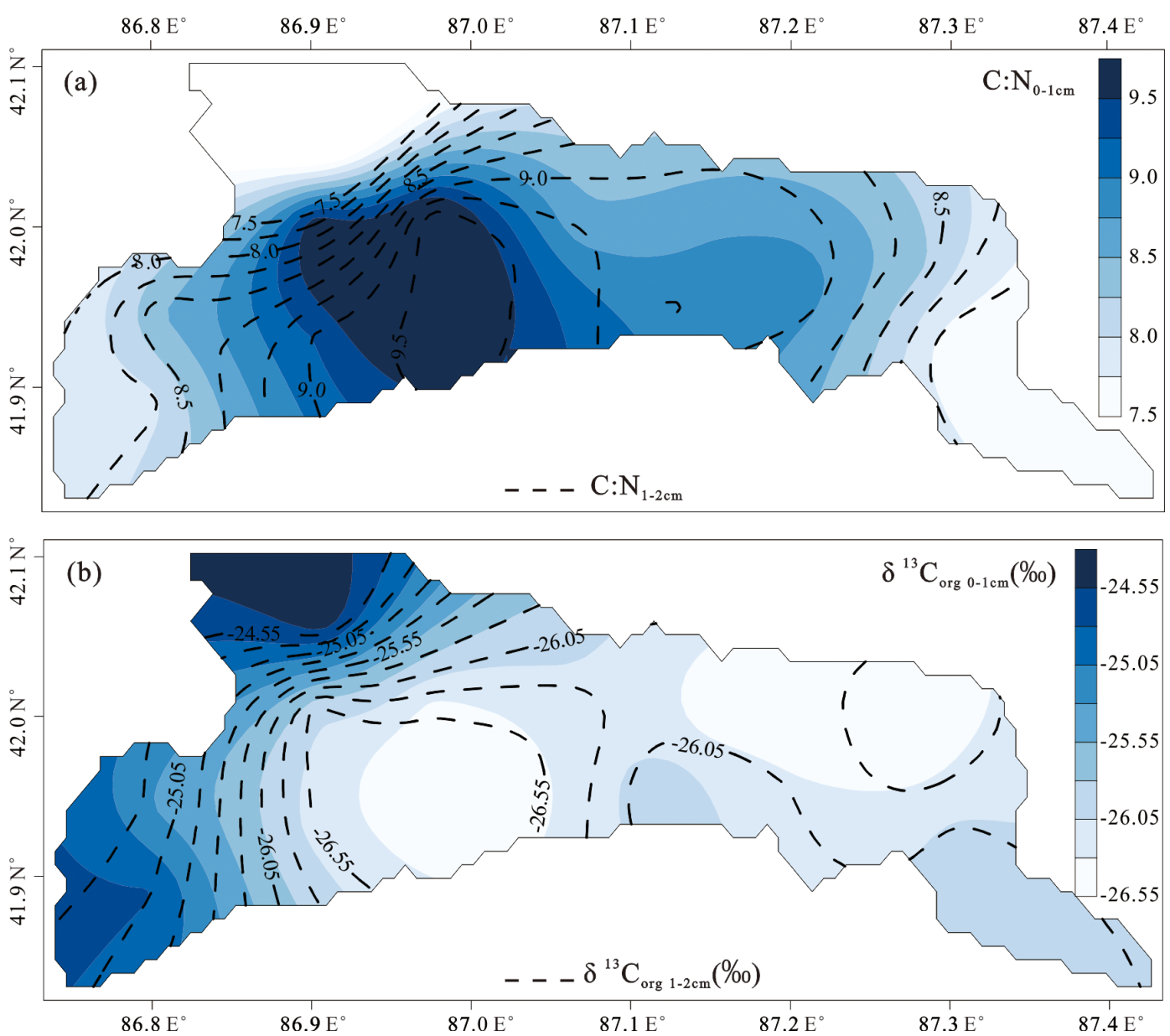

Figure 4. Spatial distribution of (a) $\mathrm{C}: \mathrm{N}$ ratio and (b) carbon stable isotope $\left(\delta^{13} \mathrm{C}_{\mathrm{org}}\right)$ of TOC in the $0-1 \mathrm{~cm}$ (color map) and $1-2 \mathrm{~cm}(\mathrm{dashed}$ lines).

Table 1. Correlation coefficient $(r)$ between various variables for the sediments.

\begin{tabular}{lrrrrrrrr}
\hline Variables & WD & DBD & $d(0.5)$ & Clay & Silt & Sand & TOC & $\delta^{13} \mathrm{C}_{\text {org }}$ \\
\hline TOC & 0.50 & $-0.58^{\mathrm{a}}$ & $-0.71^{\mathrm{b}}$ & 0.18 & $0.77^{\mathrm{b}}$ & $-0.76^{\mathrm{b}}$ & & -0.15 \\
$\mathrm{TN}$ & 0.07 & $-0.83^{\mathrm{b}}$ & $-0.60^{\mathrm{a}}$ & -0.05 & $0.79^{\mathrm{b}}$ & $-0.72^{\mathrm{b}}$ & $0.71^{\mathrm{b}}$ & 0.45 \\
$\mathrm{C}: \mathrm{N}$ & 0.50 & 0.50 & 0.01 & 0.25 & -0.19 & 0.11 & 0.14 & $-0.82^{\mathrm{b}}$ \\
$\delta^{13} \mathrm{C}_{\text {org }}$ & $-0.66^{\mathrm{a}}$ & -0.46 & -0.13 & 0.03 & 0.21 & -0.20 & -0.15 & \\
POC & -0.42 & -0.41 & 0.11 & -0.29 & 0.11 & -0.02 & 0.14 & 0.22 \\
\hline
\end{tabular}

WD: water depth, DBD: dry bulk density, $d(0.5)$ : median diameter from the $0-2 \mathrm{~cm}$ sediments. Significance of Pearson correlation is marked with ${ }^{\mathrm{a}}(p<0.05)$ and ${ }^{\mathrm{b}}(p<0.01)$ superscripts.

ues in the central north and east sections and near the mouth of the Kaidu River, but lower values in the west section and mid-south section (Fig. 3a). Further analyses showed that the highest autochthonous TOC was found near the mouth of the Kaidu River and the highest allochthonous TOC in the east section (Fig. 6). There is evidence of high productivity near the sources of nutrients, such as estuaries owing to extra nutrient input from riverine (Deng et al., 2006; Lin et al., 2002). Nutrient conditions in Bosten Lake may be largely affected by the transportation of the Kaidu River, which has a significant decline from the mouth to the east section. A similar finding was also observed in the Nam Co Lake (Wang et al., 2012).

TOC burial in sediments is a result of sedimentation of POC. Here, we compared the spatial pattern of autochthonous TOC in the $0-1 \mathrm{~cm}$ sediment with the summer POC reported by Wang et al. (2014), which showed the highest values of both variables near the mouth of the Kaidu 

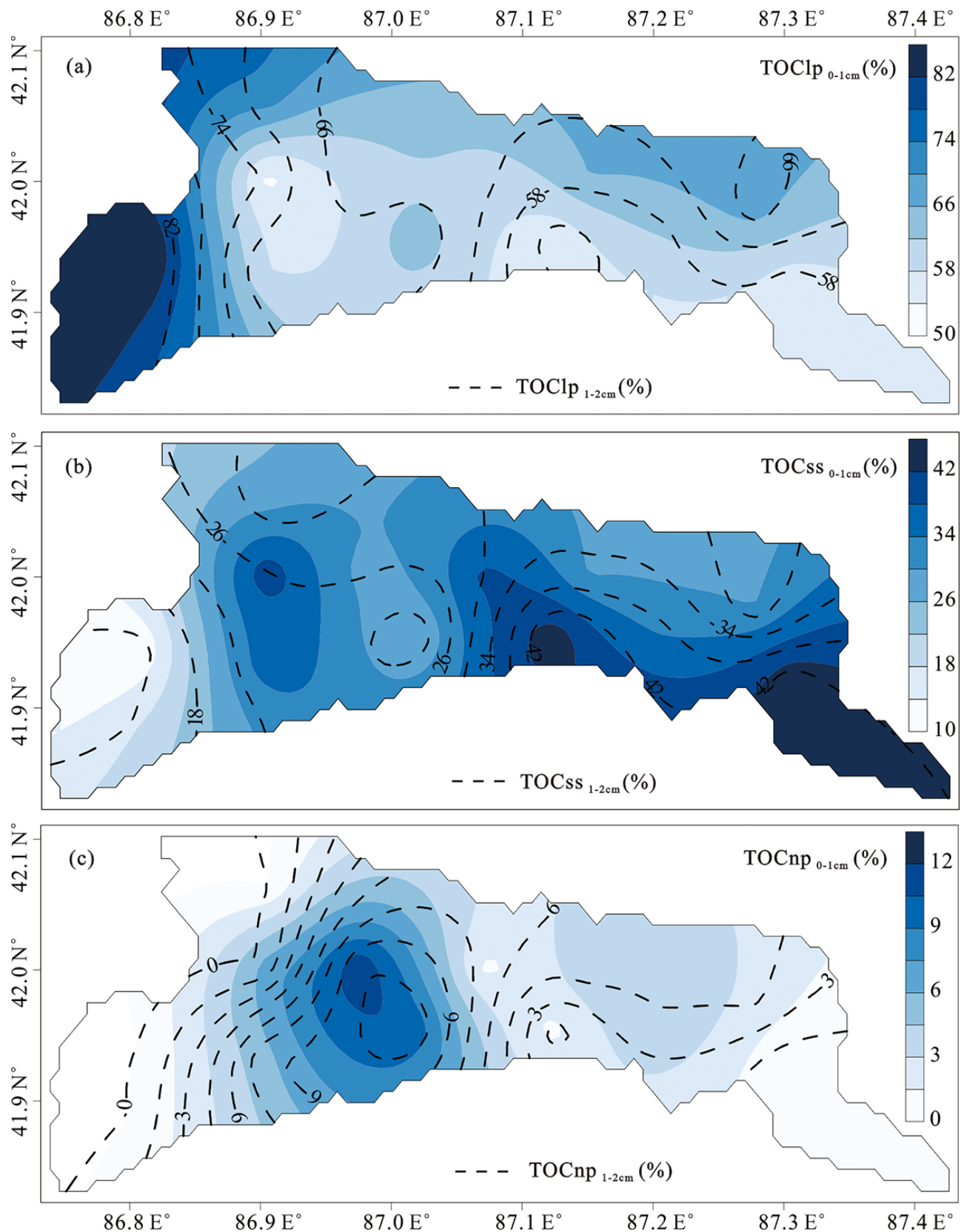

Figure 5. Spatial patterns of the relative contributions for TOC in the $0-1 \mathrm{~cm}$ (color map) and 1-2 cm (dashed lines) sediments. (a) TOC from lake plankton $\left(\mathrm{TOC}_{\mathrm{lp}}\right)$, (b) TOC from surface soils $\left(\mathrm{TOC}_{\mathrm{ss}}\right)$, and (c) TOC from native plants $\left(\mathrm{TOC}_{\mathrm{np}}\right)$.

River (Fig. 7). Statistical analysis indicated that the correlation was not significant $(r=0.14, P>0.1$, Table 1) between these two variables, which might be due to the mismatch in the locations of the lowest values. As shown in Figs. 2 and 3, coarse particle components were dominant in the mid-west section where TOC was the lowest. Table 1 also illustrates that TOC had a negative relationship with sand content and $d(0.5)$. Usually, in a relatively close hydraulic equivalence, coarser sediment particles indicated a stronger water energy environment (Jin et al., 2006; Molinaroli et al., 2009). These analyses indicated that the relatively lower TOC values in the mid-west section of Bosten Lake were attributable to both the lower POC in the water column and higher kinetic energy level.

The magnitudes and spatial distribution of TOC in lake sediment may reflect multiple, complex processes (Sifeddine et al., 2011; Woszczyk et al., 2011; Dunn et al., 2008; Wang et al., 2012). Our analyses showed a significant negative relationship between the $\delta^{13} \mathrm{C}_{\text {org }}$ value and water depth (Table 1), implying that the shallow sections in Bosten Lake 

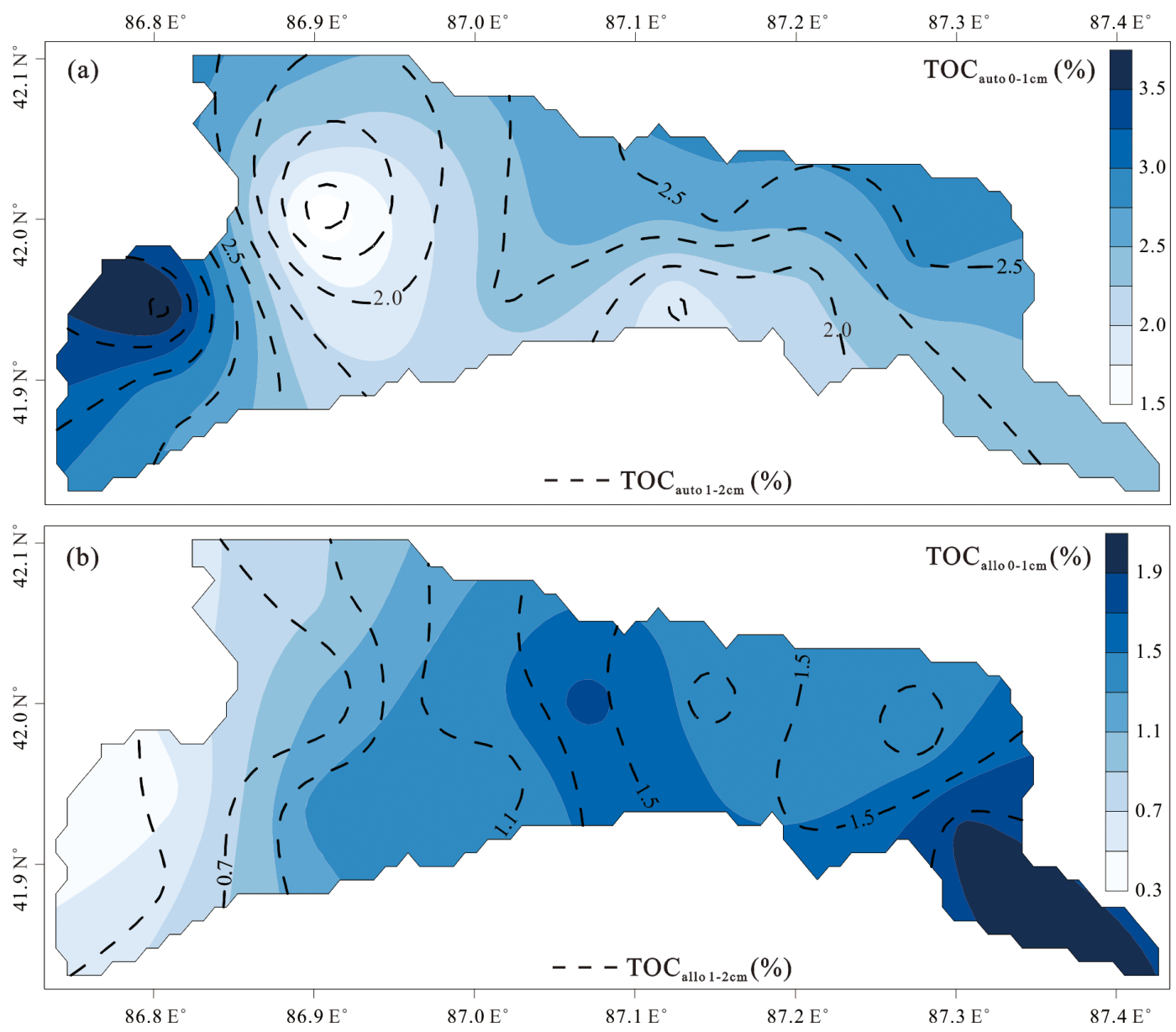

Figure 6. Spatial distributions of (a) autochthonous TOC $\left(\mathrm{TOC}_{\text {auto }}\right)$ and (b) allochthonous sources TOC (TOC allo $)$ in the $0-1 \mathrm{~cm}(\mathrm{color}$ map) and $1-2 \mathrm{~cm}$ (dashed lines) sediments.

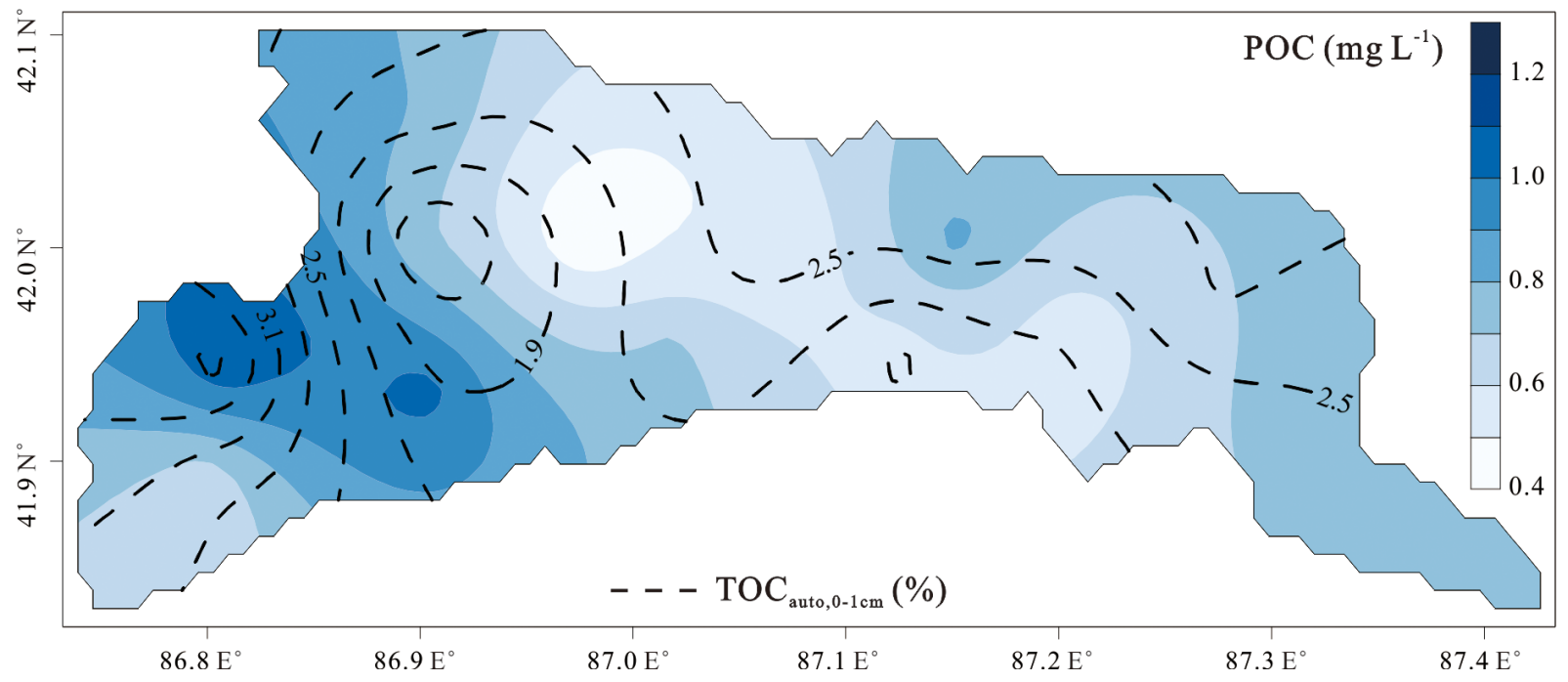

Figure 7. Spatial distributions of POC concentrations in summer (color map) and autochthonous TOC in the 0-1 cm sediment ( TOC $_{\text {auto, } 0-1 \mathrm{~cm}}$, dashed lines). POC data are from Wang et al. (2014). 
accumulated more allochthonous TOC (with less negative $\delta^{13} \mathrm{C}$ ). Apart from the lake's own characteristics (such as lake current and depth), other factors may have influences on the dynamics of TOC. For example, land use changes such as agricultural development and fertilization would enhance the riverine input of nutrients, leading to changes in lake productivity and subsequently altering TOC burial in the sediment (Rumolo et al., 2011; Lami et al., 2010; Lamb et al., 2006). There has been evidence of climate change and human activities over the past decades in the surrounding region, which has caused remarkable lake level changes in Bosten Lake (Guo et al., 2014). All these changes would have impacts on the production of POC and TOC burial. Further studies are needed to assess the spatial and temporal variations in the water column biological production to better understand the dynamics of OC in Bosten Lake and the impacts of human activity and climate change.

Acknowledgements. This study is financially supported by the National Key Basic Research Program (2013CB956602), the Special Environmental Research Funds for Public Welfare of the State Environmental Protection Administration (201309041), the Sino-German Project (GZ867), and National Pioneer Project (XDA05020202).

Edited by: B. A. Pellerin

\section{References}

Anderson, N. J., D'Andrea, W., and Fritz, S. C.: Holocene carbon burial by lakes in SW Greenland, Glob. Change Bio., 15, 25902598, 2009.

Anderson, N. J., Dietz, R. D., and Engstrom, D. R.: Land-use change, not climate, controls organic carbon burial in lakes, $\mathrm{P}$. Roy. Soc. B-Biol. Sci., 280, 1278, doi:10.1098/rspb.2013.1278, 2013.

Barnes, M. A. and Barnes, W. C.: Organic Compounds in Lake Sediments, in: Lakes, edited by: Lerman, A., Springer New York, 127-152, 1978.

Battin, T. J., Luyssaert, S., Kaplan, L. A., Aufdenkampe, A. K., Richter, A., and Tranvik, L. J.: The boundless carbon cycle, Nat. Geosci., 2, 598-600, 2009.

Bechtel, A. and Schubert, C. J.: A biogeochemical study of sediments from the eutrophic Lake Lugano and the oligotrophic Lake Brienz, Switzerland, Org. Geochem., 40, 1100-1114, 2009.

Bertrand, S., Sterken, M., Vargas-Ramirez, L., De Batist, M., Vyverman, W., Lepoint, G., and Fagel, N.: Bulk organic geochemistry of sediments from Puyehue Lake and its watershed (Chile, $40^{\circ} \mathrm{S}$ ): Implications for paleoenvironmental reconstructions, Palaeogeogr. Palaeocl., 294, 56-71, 2010.

Brodie, C. R., Leng, M. J., Casford, J. S. L., Kendrick, C. P., Lloyd, J. M., Yongqiang, Z., and Bird, M. I.: Evidence for bias in C and $\mathrm{N}$ concentrations and $\delta^{13} \mathrm{C}$ composition of terrestrial and aquatic organic materials due to pre-analysis acid preparation methods, Chem. Geol., 282, 67-83, 2011.
Burone, L., Muniz, P., Pires-Vanin, A., Maria, S., and Rodrigues, M.: Spatial distribution of organic matter in the surface sediments of Ubatuba Bay (Southeastern-Brazil), An. Acad. Bras. Cien., 75, 77-80, 2003.

Dean, W. E. and Gorham, E.: Magnitude and significance of carbon burial in lakes, reservoirs, and peatlands, Geology, 26, 535-538, 1998.

Deng, B., Zhang, J., and Wu, Y.: Recent sediment accumulation and carbon burial in the East China Sea, Global Biogeochem. Cy., 20, GB3014, doi:10.1029/2005GB002559, 2006.

Dong, X., Anderson, N. J., Yang, X., and Shen, J.: Carbon burial by shallow lakes on the Yangtze floodplain and its relevance to regional carbon sequestration, Glob. Change Biol., 18, 2205-2217, 2012.

Downing, J. A., Prairie, Y., Cole, J., Duarte, C., Tranvik, L., Striegl, R., McDowell, W., Kortelainen, P., Caraco, N., and Melack, J.: The global abundance and size distribution of lakes, ponds, and impoundments, Limnol. Oceanogr., 51, 2388-2397, 2006.

Dunn, R. J. K., Welsh, D. T., Teasdale, P. R., Lee, S. Y., Lemckert, C. J., and Meziane, T.: Investigating the distribution and sources of organic matter in surface sediment of Coombabah Lake (Australia) using elemental, isotopic and fatty acid biomarkers, Cont. Shelf Res., 28, 2535-2549, 2008.

Eksperiandova, L. P., Fedorov, O. I., and Stepanenko, N. A.: Estimation of metrological characteristics of the element analyzer EuroVector EA-3000 and its potential in the single-reactor CHNS mode, Microchem. J., 99, 235-238, 2011.

Fang, J., Wu, F., Xiong, Y., Li, F., Du, X., An, D., and Wang, L.: Source characterization of sedimentary organic matter using molecular and stable carbon isotopic composition of $n$-alkanes and fatty acids in sediment core from Lake Dianchi, China, Sci. Total Enviro., 473, 410-421, 2014.

Ferland, M.-E., del Giorgio, P. A., Teodoru, C. R., and Prairie, Y. T.: Long-term $\mathrm{C}$ accumulation and total $\mathrm{C}$ stocks in boreal lakes in northern Québec, Global Biogeochem. Cy., 26, GB0E04, doi:10.1029/2011GB004241, 2012.

Gireeshkumar, T. R., Deepulal, P. M., and Chandramohanakumar, N.: Distribution and sources of sedimentary organic matter in a tropical estuary, south west coast of India (Cochin estuary): A baseline study, Mar. Pollut. Bull., 66, 239-245, 2013.

Gudasz, C., Bastviken, D., Steger, K., Premke, K., Sobek, S., and Tranvik, L. J.: Temperature-controlled organic carbon mineralization in lake sediments, Nature, 466, 478-481, 2010.

Guo, M., Wu, W., Zhou, X., Chen, Y., and Li, J.: Investigation of the dramatic changes in lake level of the Bosten Lake in northwestern China, Theor. Appl. Climatol., 119, 341-351, 2015.

Hanson, P. C., Buffam, I., Rusak, J. A., Stanley, E. H., and Watras, C.: Quantifying lake allochthonous organic carbon budgets using a simple equilibrium model, Limnol. Oceanogr, 59, 167-181, 2014.

Jiang, J. and Huang, Q.: Distribution and variation of lakes in Tibetan Plateau and their comparison with lakes in other part of China, Water Resour. Protect., 4, 24-27, 2004.

Jin, Z., Li, F., Cao, J., Wang, S., and Yu, J.: Geochemistry of Daihai Lake sediments, Inner Mongolia, north China: Implications for provenance, sedimentary sorting, and catchment weathering, Geomorphology, 80, 147-163, 2006.

Kaushal, S. and Binford, M.: Relationship between $\mathrm{C}: \mathrm{N}$ ratios of lake sediments, organic matter sources, and historical deforesta- 
tion in Lake Pleasant, Massachusetts, USA, J. Paleolimnol., 22, 439-442, 1999.

Khim, B.-K., Jung, H. M., and Cheong, D.: Recent variations in sediment organic carbon content in Lake Soyang (Korea), Limnology, 6, 139-139, 2005.

Lamb, A. L., Leng, M. J., Umer Mohammed, M., and Lamb, H. F.: Holocene climate and vegetation change in the Main Ethiopian Rift Valley, inferred from the composition $\left(\mathrm{C} / \mathrm{N}\right.$ and $\left.\delta^{13} \mathrm{C}\right)$ of lacustrine organic matter, Quaternary Sci. Rev., 23, 881-891, 2004.

Lamb, A. L., Wilson, G. P., and Leng, M. J.: A review of coastal palaeoclimate and relative sea-level reconstructions using $\delta^{13} \mathrm{C}$ and $\mathrm{C} / \mathrm{N}$ ratios in organic material, Earth-Sci. Rev., 75, 29-57, 2006.

Lami, A., Turner, S., Musazzi, S., Gerli, S., Guilizzoni, P., Rose, N., Yang, H., Wu, G., and Yang, R.: Sedimentary evidence for recent increases in production in Tibetan plateau lakes, Hydrobiologia, 648, 175-187, 2010.

Lin, S., Hsieh, I. J., Huang, K.-M., and Wang, C.-H.: Influence of the Yangtze River and grain size on the spatial variations of heavy metals and organic carbon in the East China Sea continental shelf sediments, Chem. Geol., 182, 377-394, 2002.

Liu, K.-K. and Kao, S.-J.: A Three End-Member Mixing Model Based on Isotopic Composition and Elemental Ratio, Terrestrial, Atmos. Oc. Sci., 18, 1067-1075, 2007.

Liu, W., Li, X., An, Z., Xu, L., and Zhang, Q.: Total organic carbon isotopes: A novel proxy of lake level from Lake Qinghai in the Qinghai-Tibet Plateau, China, Chem. Geol., 347, 153-160, 2013.

Liu, X., Herzschuh, U., Wang, Y., Kuhn, G., and Yu, Z.: Glacier fluctuations of Muztagh Ata and temperature changes during the late Holocene in westernmost Tibetan Plateau, based on glaciolacustrine sediment records, Geophys. Res. Lett., 41, 2014GL060444, doi:10.1002/2014GL060444, 2014.

Meyers, P. A.: Applications of organic geochemistry to paleolimnological reconstructions: a summary of examples from the Laurentian Great Lakes, Org. Geochem., 34, 261-289, 2003.

Meyers, P. A. and Ishiwatari, R.: Lacustrine organic geochemistry - an overview of indicators of organic matter sources and diagenesis in lake sediments, Org. Geochem., 20, 867-900, 1993.

Molinaroli, E., Guerzoni, S., De Falco, G., Sarretta, A., Cucco, A., Como, S., Simeone, S., Perilli, A., and Magni, P.: Relationships between hydrodynamic parameters and grain size in two contrasting transitional environments: The Lagoons of Venice and Cabras, Italy, Sediment. Geol., 219, 196-207, 2009.

Pancost, R. D. and Boot, C. S.: The palaeoclimatic utility of terrestrial biomarkers in marine sediments, Mar. Chem., 92, 239-261, 2004.

Qin, B. and Zhu, G.: The nutrient forms, cycling and exchange flux in the sediment and overlying water system in lakes from the middle and lower reaches of Yangtze River, Sci. China Ser. D, 49, 1-13, 2006.

Qin, B., Yang, L., Chen, F., Zhu, G., Zhang, L., and Chen, Y.: Mechanism and control of lake eutrophication, Chin. Sci. Bull., 51, 2401-2412, 2006.

Rumolo, P., Barra, M., Gherardi, S., Marsella, E., and Sprovieri, M.: Stable isotopes and $\mathrm{C} / \mathrm{N}$ ratios in marine sediments as a tool for discriminating anthropogenic impact, J. Environ. Monitor., 13, 3399-3408, 2011.
Shanahan, T. M., McKay, N., Overpeck, J. T., Peck, J. A., Scholz, C., Heil Jr, C. W., and King, J.: Spatial and temporal variability in sedimentological and geochemical properties of sediments from an anoxic crater lake in West Africa: Implications for paleoenvironmental reconstructions, Palaeogeogr., Palaeocl., 374, 96-109, 2013.

Sifeddine, A., Meyers, P., Cordeiro, R., Albuquerque, A., Bernardes, M., Turcq, B., and Abrão, J.: Delivery and deposition of organic matter in surface sediments of Lagoa do Caçó (Brazil), J. Paleolimnol., 45, 385-396, 2011.

Tranvik, L. J., Downing, J. A., Cotner, J. B., Loiselle, S. A., Striegl, R. G., Ballatore, T. J., Dillon, P., Finlay, K., Fortino, K., and Knoll, L. B.: Lakes and reservoirs as regulators of carbon cycling and climate, Limnol. Oceanogr., 54, 2298-2314, 2009.

Vuorio, K., Meili, M., and Sarvala, J.: Taxon-specific variation in the stable isotopic signatures $\left(\delta^{13} \mathrm{C}\right.$ and $\left.\delta^{15} \mathrm{~N}\right)$ of lake phytoplankton, Freshwater Biol., 51, 807-822, 2006.

Wang, X., Cui, L., Xiao, J., and Ding, Z.: Stable carbon isotope of black carbon in lake sediments as an indicator of terrestrial environmental changes: An evaluation on paleorecord from Daihai Lake, Inner Mongolia, China, Chem. Geol., 347, 123-134, 2013.

Wang, X., Fang, C., Yu, Z., Wang, J., Peng, D., and Jingjing, K.: Seasonal variations of particulate and dissolved organic carbon in Bosten Lake, Xinjiang, J. Lake Sci., 26, 552-558, 2014.

Wang, X., Wang, J., Xu, M., Zhang, W., Fan, T., and Zhang, J.: Carbon accumulation in aird croplands of northwest China: pedogenic carbonate exceeding organic carbon, Sci. Rep-UK, 5, 11439, doi:10.1038/srep11439, 2015.

Wang, Y., Zhu, L., Wang, J., Ju, J., and Lin, X.: The spatial distribution and sedimentary processes of organic matter in surface sediments of Nam Co, Central Tibetan Plateau, Chin. Sci. Bull., 57, 4753-4764, 2012.

Woszczyk, M., Bechtel, A., Gratzer, R., Kotarba, M. J., Kokociński, M., Fiebig, J., and Cieśliński, R.: Composition and origin of organic matter in surface sediments of Lake Sarbsko: A highly eutrophic and shallow coastal lake (northern Poland), Org. Geochem., 42, 1025-1038, 2011.

Wu, F., Xu, L., Sun, Y., Liao, H., Zhao, X., and Guo, J.: Exploring the relationship between polycyclic aromatic hydrocarbons and sedimentary organic carbon in three Chinese lakes, J. Soil. Sediment., 12, 774-783, 2012.

Wu, J., Huang, C., Zeng, H., GerhardH, S., and Rick, B.: Sedimentary evidence for recent eutrophication in the northern basin of Lake Taihu, China: human impacts on a large shallow lake, J. Paleolimnol., 38, 13-23, 2007.

Wu, J., Ma, L., and Zeng, H.: Water Quality and Quantity Characteristics and Its Evolution in Lake Bosten, Xinjiang over the Past 50 Years, Sci. Geogr. Sinica, 33, 231-237, 2013.

Yu, F., Zong, Y., Lloyd, J. M., Huang, G., Leng, M. J., Kendrick, C., Lamb, A. L., and Yim, W. W. S.: Bulk organic $\delta^{13} \mathrm{C}$ and C/N as indicators for sediment sources in the Pearl River delta and estuary, southern China, Estuar. Coast. Shelf S., 87, 618-630, 2010.

Zhang, C., Mischke, S., Zheng, M., Prokopenk, A., Guo, F., and Feng, Z.: Carbon and Oxygen Isotopic Composition of SurfaceSediment Carbonate in Bosten Lake (Xinjiang, China) and its Controlling Factors, Acta Geol. Sin.-Engl., 83, 386-395, 2009. 
Zhang, J.: Impacts of land use on soil organic matter in Yanqi Basin, $\mathrm{PhD}$ thesis, Xinjiang Institute of Ecology and Geography, Chinese Academy of Sciences, Urumqi, Xinjiang, China, 2013.
Zhu, Z., Chen, J., and Zeng, Y.: Abnormal positive delta C-13 values of carbonate in Lake Caohai, southwest China, and their possible relation to lower temperature, Quatern. Int., 286, 85-93, 2013. 